\title{
Social representations of HIV/AIDS by older people and the interface with prevention
}

\author{
Representações sociais do HIV/Aids por idosos e a interface com a prevenção \\ Representaciones sociales del VIH/SIDA de ancianos y la interrelación con la prevención
}

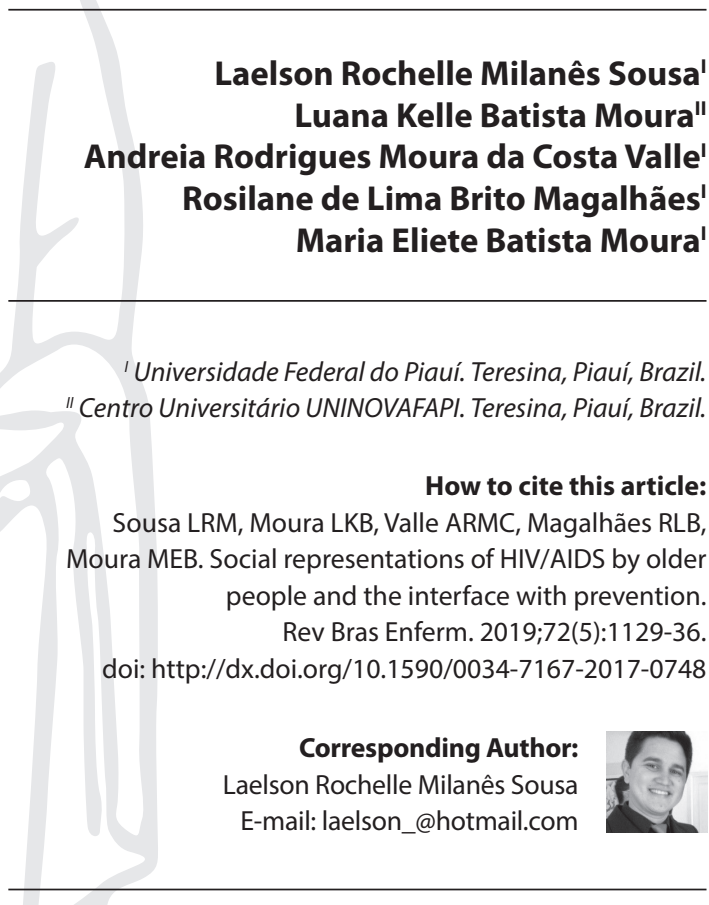

Submission: 10-26-2017

Approval: 02-07-2018

\begin{abstract}
Objective: To apprehend the social representations elaborated by older people about HIV/AIDS and to understand how they relate to the prevention of HIV infection. Method: Descriptive and qualitative research based on the Theory of Social Representations with 42 older people assisted at primary care. Data were produced through in-depth interviews with a semi-structured instrument, processed in the IRaMuTeQ software, and analyzed by means of the descending hierarchical classification. Results: Five classes emerged: "HIV/AIDS: a problem of young people"; "Quality of life improvement for people living with HIV/AIDS"; "Vulnerability to HIV/AIDS among heterosexual women in a stable union"; "HIV/AIDS Information Network: process of creation and transformation of social representations" and "Prevention versus stigma". Final considerations: The social representations that older people have about HIV/AIDS influence the adoption of preventive measures negatively because stigma is present and HIV/AIDS is attributed to young men, and to men who have sex with other men.
\end{abstract}

Descriptors: Social Psychology; HIV; Aged; Acquired Immunodeficiency Syndrome; Primary Health Care.

\section{RESUMO}

Objetivo: Apreender as Representações Sociais elaboradas por idosos sobre o HIV/Aids e compreender como elas se relacionam com a prevenção da infecção pelo HIV. Método: Pesquisa descritiva e qualitativa fundamentada na Teoria das Representações Sociais, com 42 idosos atendidos na atenção primária. Os dados foram produzidos por meio de entrevistas, em profundidade, com um instrumento semiestruturado, processados no software IRaMuTeQ e analisados pela Classificação Hierárquica Descendente. Resultados: Emergiram cinco classes: "HIV/Aids: um problema de jovens"; "Melhoria da qualidade de vida de pessoas vivendo com HIV/Aids"; "Vulnerabilidade ao HIV/Aids de mulheres heterossexuais em união estável"; "Rede de informações sobre HIV/Aids: Processo de criação e transformação das Representações Sociais"; e "Prevenção versus Estigma". Considerações Finais: As representações sociais que os idosos têm sobre o HIV/Aids influenciam de forma negativa na adoção de medidas preventivas, pois o estigma está presente e o HIV/Aids é atribuído a jovens e homens que fazem sexo com homens. Descritores: Psicologia Social; HIV; Idoso; Síndrome de Imunodeficiência Adquirida; Atenção Primária à Saúde.

\section{RESUMEN}

Objetivo: Comprender las Representaciones Sociales elaboradas por ancianos sobre el $\mathrm{VIH} /$ SIDA y entender cómo se relacionan con la infección por VIH. Método: Investigación descriptiva, cualitativa, fundamentada en la Teoría de las Representaciones Sociales, con 42 ancianos atendidos en atención primaria. Datos recolectados mediante entrevistas en profundidad aplicando instrumento semiestructurado, procesados en software IRaMuTeQ y analizados por Clasificación Jerárquica Descendente. Resultados: Surgieron cinco clases: "VIH/SIDA: un problema de jóvenes"; "Mejora de calidad de vida de personas que viven con VIH/SIDA"; "Vulnerabilidad al VIH/SIDA de mujeres heterosexuales en pareja estable"; "Red de informaciones sobre VIH/SIDA: Proceso de creación y transformación de las Representaciones Sociales"; y "Prevención versus Estigma". Consideraciones Finales: Las representaciones sociales que los ancianos tienen respecto del VIH/SIDA influyeron negativamente a la adopción de medidas preventivas, pues el estigma está presente y el VIH/SIDA es atribuido a jóvenes y hombres que tienen sexo con otros hombres.

Descriptores: Psicología Social; VIH; Anciano; Síndrome de Inmunodeficiencia Adquirida; Atención Primaria de Salud. 


\section{INTRODUCTION}

After 30 years of their discovery, the Acquired Immunodeficiency Syndrome (AIDS) and the Human Immunodeficiency Virus (HIV) are still important objects of social research. HIV/AIDS causes damage to health, and produces negative images, even with advances in the treatment ${ }^{(1)}$. Reconfigurations of the popular representation of the disease are already noticed, although in a discrete reduction of its unfavorable image, in different realities, both from the perspective of users and health professionals ${ }^{(2)}$.

A transition of meaning in the popular perception of AIDS is observed, which is no longer directly related to death, and is perceived as a chronic treatable disease that enables the prolongation and improvement of the quality of life for people living with HIV/AIDS. Such advances have a direct association with antiretroviral therapies ${ }^{(3-4)}$.

In addition to the chronicity of the disease, the rapid global aging of the population is associated with a consequent increase in the number of older people living with HIV/AIDS ${ }^{(5)}$. With the new population demand, new challenges arise. Understanding the sexual behavior of older people and their vulnerabilities to sexually transmitted infections (STIs), such as HIV/AIDS, emerges as a contemporary issue.

The compliance of older people to HIV/AIDS preventive methods, such as the use of condoms in sexual intercourses, has been low in China and the United States among those who have an emotional engagement with sex workers ${ }^{(6-7)}$. In Uganda, low adherence to condom use was reported by older people with an active sex life ${ }^{(8)}$, and the same situation was found with residents in New York ${ }^{(9)}$. In addition, a review has shown that older Americans underestimate the risk of being infected with $\mathrm{HIV}^{(10)}$. Despite distinct social, economic, and cultural contexts, the condition appears to be similar.

In Brazil, culturally, the sexual behavior of older people is overlooked by the population and health professionals, who make these practices invisible and do not act in an efficient way to mitigate the risks of HIV infection ${ }^{(11)}$.

In recent years, the sexual activity of older people has been supported by the increase of new technologies, such as artificial lubricants that help women in the postmenopausal period ${ }^{(12)}$. Innovations like this can improve the performance of sexual function and make it more attractive. In addition, low knowledge about the virus and non-compliance to preventive methods to reduce the risk of infection in sexual activity makes the elderly population vulnerable, making the understanding of how older people represent HIV/AIDS a priority.

Most current studies using the Theory of Social Representations in the thematic field of HIV/AIDS mainly address two aspects: people living with HIV/AIDS, and professionals who deal directly with these people ${ }^{(13-14)}$. There is also a discrete portion of studies that investigate people with negative serology and professionals who do not directly deal with the virus in their routines ${ }^{(15)}$.

It is relevant to search for the understanding of social groups that do not live with HIV/AIDS or that do not know their serology, because there is the possibility of working with participants who build their representations without necessarily having a direct link with the infection. Even without a direct connection, these people are influenced by secondary sources of information, such as television, the internet, and the everyday social environment, through the sharing of ideas.

\section{OBJECTIVE}

To apprehend the social representations elaborated by older people assisted in basic health units (BHU) about HIV and AIDS, and to understand how these social representations relate to the prevention of HIV infection.

\section{METHOD}

\section{Ethical aspects}

The research was approved by the Research Ethics Committee of the Federal University of Piauí. During the production of data, the objectives, risks and benefits were clarified to the participants in order to obtain collaboration with the research in an autonomous way. All participants read and signed a free and informed consent form.

\section{Type of study and theoretical-methodological framework}

This was a descriptive study, using a qualitative approach based on Serge Moscovici's Theory of Social Representations (TSR). In the TSR, it is admitted that social representations are constructed and reconstructed by the social agents being allocated according to their position in the universe of social communication, with the individual being active in the construction of their own representations ${ }^{(16)}$.

\section{Study scenario}

The research was carried out in primary health care, from a $\mathrm{BHU}$ located in the Southern region of the city of Teresina, state of Piauí, Brazil. The BHU in question serves the population of the neighborhood and adjacent regions, including the surrounding neighborhoods. Approximately 16,000 people are directly or indirectly benefited.

The above-mentioned BHU was chosen because it covers a health area recognized for its activities developed with the older population. In the space, there are 04 family health teams with approximately 800 older people enrolled and assisted by the health teams at the BHU and at home.

\section{Study participants}

The number of participants in the study was 42 older people, selected by convenience, with the final number based on theoretical saturation criteria, as the data did not produce new relevant or distinct information ${ }^{(17-19)}$. The following inclusion criteria were followed: people aged 60 and over, of both genders, enrolled in the BHU and seeking services at the health unit, participating in the activities developed by the teams and presenting cognitive or mental capacity checked with the Mini-Mental State Examination.

The exclusion criteria adopted were: older people with impaired hearing acuity and those who were unable to develop a dialogue with the researcher. 


\section{Data production technique and instrument}

Data were produced by means of in-depth interviews conducted in a reserved room of the BHU during the months of May to August of 2016 based on free demand. The interview was guided by a semistructured instrument divided into two parts: the first one containing data on the sociodemographic characterization of the older people and the second consisting of open-ended questions about HIV/ AIDS. Data were produced in two stages: first, the sociodemographic characterization was performed and, in the second stage, the participants were invited to answer open-ended questions about HIV/AIDS including previous knowledge about prevention, transmission and participation in educational activities for prevention. The interviews were recorded and lasted for 40 minutes, on average.

\section{Treatment and data analysis}

Data were processed using the IRaMuTeQ (Interface de R pour les Analyses Multidimensionnelles de Textes et de Questionnaires) ${ }^{(20)}$, and analyzed using the descending hierarchical classification ${ }^{(21)}$. The IRaMuTeQ software has gained prominence in qualitative studies because it uses statistical techniques to help researchers to grasp the social object and to create classes of analysis based on the apprehension and identification of the units of meaning ${ }^{(22-23)}$.

\section{RESULTS}

Of the 42 participants, 36 were women, aged $60-70$ years (66.6\%), 38 were retired (90.5\%), 22 were married $(52.4 \%), 38$ were Catholic (90.5\%), 18 with an income of one to two minimum wages (42.9\%), and 17 had complete primary education (40.5\%).
IRaMuTeQ recognized the separation of the corpus into 424 elementary text units, from 509 text segments. There were 18,136 occurrences, with use of $83.30 \%$ of the total corpus. Based on the descending hierarchical classification, the textual domains were analyzed and interpreted to give meaning to the classes. The segments used were divided into five classes, as shown in Figure 1.

\section{Class 1: HIV/AIDS: a problem of young people}

In this class, older people identify young people as the most vulnerable group to HIV/AIDS. Senile people exclude themselves from the risks of acquiring the virus and perceive the disease as a problem of the others.

Young people are more likely to get it, it's very easy, because today freedom is too great. You rarely see an older person with AIDS or a younger woman. (Int. 6)

I think it's just young people who can get AIDS more easily. Because young people have no sense of things, but a person like me, at my age ... Then we think about things, but these kids now do not think at all. (Int. 21)

Most young people want to do it their way. I even have a very beautiful message that says: we should enjoy young people while they are children because when they grow up they will listen to the others. (Int. 29)

Believing that HIV/AIDS is a problem of young people hinders the adoption of preventive measures, which influences the increase of susceptibility to HIV.

\begin{tabular}{|c|c|c|c|c|c|c|c|c|c|}
\hline \multicolumn{10}{|c|}{ SOCIAL REPRESENTATIONS OF HIV/AIDS BY OLDER PEOPLE } \\
\hline & & & & & & & 工 & & \\
\hline \multicolumn{2}{|c|}{ Class 1} & \multicolumn{2}{|c|}{ Class 2} & \multicolumn{2}{|c|}{ Class 3} & \multicolumn{2}{|c|}{ Class 4} & \multicolumn{2}{|c|}{ Class 5} \\
\hline \multicolumn{2}{|c|}{$\begin{array}{l}92 \mathrm{ECU}^{*}(21.7 \%) \\
\text { HIV/AIDS: a problem of } \\
\text { young people }\end{array}$} & \multicolumn{2}{|c|}{$\begin{array}{l}66 \text { ECU (15.57\%) } \\
\text { Quality of life } \\
\text { improvement of people } \\
\text { living with HIV/AIDS }\end{array}$} & \multicolumn{2}{|c|}{$\begin{array}{l}78 \text { ECU (18.4\%) } \\
\text { Vulnerability to HIV/ } \\
\text { AIDS of heterosexual } \\
\text { women in a stable union }\end{array}$} & \multicolumn{2}{|c|}{$\begin{array}{l}92 \text { ECU ( } 21.7 \%) \\
\text { HIV/AIDS information } \\
\text { network: process } \\
\text { of creation and } \\
\text { transformation of SR }\end{array}$} & \multicolumn{2}{|c|}{$\begin{array}{l}96 \mathrm{ECU}(22.64 \%) \\
\text { Prevention versus stigma }\end{array}$} \\
\hline Word & $\mathrm{X}^{2}$ & Word & $\mathrm{X}^{2}$ & Word & $\mathrm{X}^{2}$ & Word & $\mathrm{X}^{2}$ & Word & $\mathrm{X}^{2}$ \\
\hline Like this & 40.4 & Today & 38.6 & Over there & 54.3 & Never & 82.1 & To use & 84.7 \\
\hline Age & 27.6 & Treatment & 35.0 & To live & 31.2 & Television & 77.6 & To prevent & 68.3 \\
\hline To think & 25.5 & More & 34.8 & Woman & 29.2 & To talk & 76.1 & Sexual & 60.5 \\
\hline Way & 20.1 & To get & 32.1 & Home & 26.5 & To speak & 41.6 & Condom & 53.4 \\
\hline Cruel & 18.2 & Good & 29.6 & To leave & 21.6 & To hear & 31.1 & Caution & 40.7 \\
\hline Right & 17.0 & To live & 24.5 & Street & 21.6 & Gas station & 25.6 & Blood & 39.9 \\
\hline Really & 15.8 & To discover & 21.9 & Boy & 19.1 & Old man & 24.4 & Relationship & 36.1 \\
\hline Head & 14.5 & Enlightened & 21.9 & To die & 18.7 & Son & 23.5 & Syringe & 27.8 \\
\hline To need & 14.0 & Difficult & 18.2 & Physician & 18.4 & To see & 23.3 & Saliva & 24.3 \\
\hline So & 13.6 & Medication & 18.2 & Husband & 18.1 & Lecture & 21.9 & Sex & 19.6 \\
\hline Child & 13.6 & Medicine & 17.2 & To decease & 17.9 & To participate & 18.2 & Prevention & 19.2 \\
\hline Mother & 11.6 & Now & 14.4 & To attend & 17.9 & To understand & 17.0 & Relationship & 17.2 \\
\hline
\end{tabular}

Note - *ECU - Elementary Context Unit

Figure 01 - Thematic structure of the social representations of HIV/AIDS by the older people 


\section{Class 2: Quality of life improvement of people living with HIVIAIDS}

A change in the representation of AIDS was observed, which is no longer directly associated with death and is now seen as a chronic disease due to the influence of antiretroviral therapy.

In the beginning, when it was discovered, it killed faster, but because of the drugs, the cocktails, the person lasts even longer. (Int. 7)

Today, with the technology, with more powerful drugs, one can live with the disease, such as diabetes, high blood pressure. I know people like that, I'm sixty-three myself and I have diabetes and controlled high blood pressure and I live a normal life. (Int.13)

Older people attribute to AIDS the image of a treatable chronic disease. This is due to antiretroviral therapies. It is noticed that the knowledge was incorporated in people's daily life, and has transformed their representations acquired in the first years of the discovery of the disease.

However, even with advances in treatment, with an increase in the expectation and quality of life and a discrete representational change, there are remnants of the anchorage of AIDS in images conveyed at the beginning of the disease, with a direct association with death.

In my opinion it is a cancer with a different name that people do not even like to say the name cancer, they call it that disease, that problem [...] which they cannot absorb due to the very high degree of lack of cure. Because when a person thinks he/she has cancer, it's the end! It has come to a full stop. It's the same way with AIDS. (Int. 18)

It's very dangerous, it's death! Got it and that's it. Only God, because everything is possible for Him, but not for us humans. It is like cancer, here is the medicine that cures cancer, yet there is none. (Int. 29)

\section{Class 3: Vulnerability to HIV/AIDS of heterosexual women in a stable union}

Older people attribute the risk of contamination to women in a stable heterosexual relationship, and indicate the spouses as unilateral responsible for the contamination, anchoring themselves in Brazilian cultural elements, such as patriarchy and the view that only men are responsible for the transmission, victimizing the female figure.

Those who are more likely to get AIDS, sometimes even a married woman, whose husband is a street womanizer. He catches it in the street and transmits it to his wife. It's the most common thing that's happening, it's very common. I know a woman that had a husband and she caught it from him and today she's under treatment, but she has it because she caught it from her husband. (Int. 37)

Our husband, we don't know what they're doing outside home. Men will be men, that is, we don't know. No matter how hard I try, I never knew anything about him, never knew. (Int. 4)

A married woman can catch it from her husband if he does it in the street without a condom, married women can catch it from their own husbands. (Int. 14)

\section{Class 4: HIV/AIDS information network: process of creation and transformation of $S R$}

This class shows social interaction among senile people and how information about HIV/AIDS arrives and is shared. The influence of television media in the process of creation, evolution and transformation of the social representations of HIV/AIDS by the older study participants is notorious. Personal interaction takes place among members of the community of residence of older people who share information about HIV/AIDS in daily life, creating an information network.

Things are changing today. I see people talking about it, I also see it on television programs because I watch these programs that talk about health a lot. (Int. 4)

I'm very keen on the internet, I like to listen, I like to participate, I really like listening to talks on television. (Int.11)

Having knowledge about HIV/AIDS built and influenced by the media can be a problem and hinder prevention, as this information may not be mediated by health professionals.

\section{Class 5: Prevention versus stigma}

In this class, condom is mentioned as the main preventive method, associated with the information about virus transmission routes.

I always told her [daughter] to prevent herself, to have sex with a condom, and she insisted that she did not like to use it, but even so I always warned her to take the contraceptive pill and use the condom to avoid AIDS and other venereal diseases. (Int. 8)

Condoms are available and people do not want them. There are few people who want it, because condoms are not only for preventing children, but for avoiding illnesses, and when you do not use and have sex with an already infected person, you can be sure that you'll be the next one. (Int. 9)

Condoms are identified as the only method of HIV/AIDS prevention, with limited knowledge. In addition, older people do not perceive themselves as vulnerable and indicate other people to use condoms.

Moreover, stigma is present in the analyzed speech:

For me, people at higher risk of getting this disease are those who [...] How do you say that? Who are [...] who have sex with other men, I don't remember the name, but it is men with men. (Int.1)

The risk group everyone knows, I have nothing against, I respect, I live very well with them, they are people too, when they really assume that, they are really great people, they are homosexuals, a risk group. (Int. 18)

Older people mentioned old risk groups described in the prelude to the disease: such as injecting drug users, homosexuals and sex workers. These social representations refer to the stigma of the disease. 
According to the Descending Hierarchical Classification, through the relationship between classes (Figure 1), social representations of HIV/AIDS have demonstrated that HIV/AIDS is seen as a problem for the other, especially of younger people, and quality of life improvement for the people living with HIV was indicated. Such representations are constructed and transformed through a network of information, encompassing television programs and the social interaction itself in the community. The adoption of preventive measures has a negative influence, because even if the older person knows how to prevent it, prevention is attributed to third parties. Finally, older people know the traditional forms of prevention, but the stigma observed in the statements tends to discourage them from adopting preventive methods, such as the use of condoms.

\section{DISCUSSION}

Older people are especially vulnerable to STIs because they exclude themselves from risks and have little knowledge on the subject. Authors reinforce that educational actions should be directed towards social deconstruction of the knowledge of the older people about HIV/AIDS, which is seen by them as other people's health problem ${ }^{(24)}$. Crediting HIV/AIDS to a youth problem depreciates the adoption of preventive measures, which influences the increase of susceptibility to HIV.

Even among senile people living with HIV who are assisted in specialized centers, the knowledge about virus transmission routes is low, and has gaps that interfere in the adoption of preventive measures ${ }^{(25)}$.

At present, efforts have been made to improve the knowledge of older people about STIS/AIDS, including construction and validation of educational guides for prevention, focusing on ways of transmission, and demystifying common-sense narratives and taboos using appropriate language and content ${ }^{(26)}$.

Older people attribute to AIDS the image of a treatable chronic disease. The advances obtained through antiretroviral therapy increased life expectancy of people with HIV/AIDS and led to changes in the popular perception of the disease, which has come to be seen as a process of chronic illness. In the world, antiretrovirals have been responsible for nearly $50 \%$ reduction in AIDS-related deaths since $2005^{(3)}$.

However, even if older people attribute an image of chronicity to AIDS, causing a discrete representational change, we can see that there are remnants of the anchorage of the disease on images constructed in the first decades of the disease, with a direct association with death.

The memories of death that are shared by the group are symbolically represented in a singular way, because the knowledge of other diseases is incorporated in daily life, and shared jointly by the group to reify AIDS. The images constructed in the past of the disease are still present in contemporary society and have a strong association with suffering and death, even among health professionals, which corroborates the stigma and discriminatory behavior that remain in the representations ${ }^{(27)}$. The perspective of representational change is slow and can be perceived in the older people as the disease gets far from the fatal consequence ${ }^{(28)}$.

The attribution of responsibility for the cases of infection of women in a stable heterosexual relationship to the figure of the man brings negative implications for safe sexual practices, and shows the need for educative actions of prevention with a focus on the couple, especially for the beliefs associated with the passivity of the woman in the sexual relation.

Women living with HIV in South Africa found it difficult to discuss prevention methods with the partner ${ }^{(29)}$. However, in the context of research with black women, they have had positive results in encouraging partners to test for $\mathrm{HIV}^{(30)}$.

For the implementation of educational strategies aimed at couples, health services must establish a relationship of trust with users. A difficulty faced by Canadian black women in adhering to HIV prevention was the lack of empathy among health professionals ${ }^{(31)}$. It is highlighted that older women living with HIV suffer from greater discrimination and face difficulties in adhering to safe sex practices, including access to condoms ${ }^{(32)}$.

Regarding the network of information to which the older people have access, it is well known that over the years television and HIV/AIDS have not established good partnerships due to sensationalist reports edited by some communication vehicles with large audiences. Knowledge about HIV/AIDS that is constructed and influenced by the media can be biased and interfere with the adoption of safe sex practices according to the sources of information that prioritize the audience in numbers, despite their social roles ${ }^{(33)}$.

The role of the media in the construction of images of HIV/ AIDS is extensively described in the current literature and tells the history of dissemination of unfavorable images related to fear of coping with the disease and strong association with death. Negative feelings associated with discrimination were reinforced by sensationalist reports that integrated the disease into socially reprehensible behaviors, causing condemnation and social death for people living with $\mathrm{HIV}^{(33)}$.

The processes of stigmatization and discrimination adopted by society and health services are influenced by the media through appealing reports with the objective of keeping the spectators' attention, and creating counterproductive symbolism corroborated over the years. In the first decades of the epidemic, the information published by the media was largely controlled by a lack of knowledge about the virus and the disease, so the immediacy of the news led to the dissemination of misleading information on television and radio channels ${ }^{(33)}$.

However, mass media can be used as a powerful tool for HIV/ AIDS prevention when media content is mediated by health institutions. Successful experiences were observed in the United States with media campaigns used to delay sexual initiation among young African-Americans and whites $^{(34)}$. Other positive experiences were observed in Bangladesh ${ }^{(35)}$. In Brazil, regularity in preventive campaigns for HIV/AIDS in large media is seasonal and campaigns for older people are rare.

In terms of prevention, condoms are identified as the main prevention method for HIV/AIDS. However, older people do not perceive themselves as vulnerable and indicate other people to use condoms.

The limited compliance of older people to the use of condoms is a recurring issue in international studies and is influenced by issues such as low level of knowledge about the virus, affective involvement with sexual partners, and multiplicity of partners ${ }^{(7,}$ 
36). The low compliance to condom use among older people was evidenced by North American researchers ${ }^{(7)}$.

Although older people indicate condoms as the primary prevention method, and demonstrate limited knowledge about the transmission of the virus, symbolic stigma emerges in their speeches.

The damage caused by stigma affects both compliance to HIV/AIDS treatment and prevention, and quality of life. Negative implications of the stigma can reach all levels of health promotion $^{(37)}$. Negative effects of the stigma were observed among women living with HIV in the United States ${ }^{(38)}$ and similar findings in Indonesia(39).

\section{Study limitations}

The main limitation of this study derives from the essential characteristics of its qualitative methodological approach and the alignment with the theoretical proposal of analysis, with the research being carried out in a $\mathrm{BHU}$, thus being limited to investigate a restricted population in depth. In addition, the sample was mostly female and may have influenced the representations listed.

\section{Contributions to the areas of nursing, health and public policies}

This study contributes to the critical reflection on HIV/AIDS prevention actions that tend to be directed towards younger groups of the population, disregarding people over sixty years old. Thus, it can be a source of primary data for future studies that seek evidence to structure and implement educational strategies for HIV/AIDS prevention among older people.

\section{FINAL CONSIDERATIONS}

The study demonstrates that the social representations elaborated by older people assisted at basic health units on HIV/ AIDS are within classes of meaning that assimilate it as a typical problem of young people, who are perceived as more vulnerable and susceptible, with vulnerability extended to women in a heterosexual and stable relationship; a disease that is amenable to treatment but which still bears the stigma of death associated with it, especially by the reinforcement of the media in this regard; the means of prevention are informed mainly by the television media and condom is the main instrument; homosexual sex among men is still mentioned as one of the central ways of contagion, corroborating the marginalizing discourse of the first decades of the virus epidemic, keeping older people far from compliance to preventive practices.

Dialogues on the sexual practices of older people should be encouraged because considering older people as potentially capable of having an active sex life is the first step in the development of preventive interventions that improve knowledge about HIV/AIDS.

\section{FUNDING}

The main author was provided with a scholarship by the Coordination for Improvement of Higher Education Personnel (CAPES).

\section{REFERENCES}

1. Mergui A, Giami A. Representations of sexuality among HIV-positive young adults. Sexol [Internet]. 2014 [cited 2017 Mar 14];23(1):5-8. Available from: http://www.sciencedirect.com/science/article/pii/S1158136013001746

2. Teixeira E, Oliveira DCO. Representações sociais de educação em saúde em tempos de AIDS. Rev Bras Enferm [Internet]. 2014 [cited 2017 Jan 23];67(5):810-7. Available from: http://www.scielo.br/pdf/reben/v67n5/0034-7167-reben-67-05-0810.pdf

3. Programa Conjunto das Nações Unidas sobre HIV/Aids - UNAIDS[Internet]. 2017 [cited 2017 Aug 2]. Available from: http://unaids.org.br/

4. Queiroz AAFLN, Sousa ÁFL, Araújo TME, Oliveira FBM, Moura MEB, Reis RK. A review of risk behaviors for hiv infection by men who have sex with men through geosocial networking phone apps. J Assoc Nurses AIDS Care [Internet]. 2017 [cited Aug 20];28(5):807-18. Available from: http://www.sciencedirect.com/science/article/pii/S1055329017300869

5. Organização Mundial da Saúde-OMS. Relatório Munidal de envelhecimento e saúde [Internet]. 2015 [cited 2016 Dec 12]. Available from: http://sbgg.org.br/wp-content/uploads/2015/10/OMS-ENVELHECIMENTO-2015-port.pdf

6. Chen Y, Bussell SA, Shen Z, Tang Z, Lan G, Zhu Q, et al. Declining inconsistent condom use but increasing HIV and syphilis prevalence among older male clients of female sex workers: analysis from sentinel surveillance sites (2010-2015), Guangxi, China. Medicine [Internet]. 2016 [cited 2017 Aug 4];95(22):1-7. Available from: https://www.ncbi.nlm.nih.gov/pubmed/27258500

7. Milrod C, Monto M. Condom use, sexual risk, and self-reported STI in a sample of older male clients of heterosexual prostitution in the United States. Am J Mens Health [Internet]. 2016 [cited 2017 Mar 17];10(4):296-305. Available from: https://www.ncbi.nlm.nih.gov/ pubmed/26739295

8. Negin J, Geddes L, Brennan-Ing M, Kuteesa M, Karpiak S, Seeley J. Sexual behavior of older adults living with HIV in Uganda. Arch Sex Behav[Internet]. 2016 [cited 2017 Jan 18];45(2):441-9. Available from: https://www.researchgate.net/ publication/281521201_Sexual_Behavior_of_Older_Adults_Living_with_HIV_in_Uganda

9. Starks TJ, Millar BM, Parsons JT. Predictors of condom use with main and casual partners among HIV-positive men over 50. J Health Psychol [Internet]. 2015 [cited 2017 Jan 23];34(11):1116-22. Available from: https://www.ncbi.nlm.nih.gov/pubmed/26010719

10. Pilowsky DJ, Wu LT. Sexual risk behaviors and HIV risk among Americans aged 50 years or older: a review. Subst Abuse Rehabil [Internet]. 
2015 [cited 2017 Jan 23];6:51-60. Available from: https://www.ncbi.nlm.nih.gov/pubmed/25960684

11. Torres CC, Bezerra VP, Pedroza AP, Silva LM, Rodrigues TP, Coutinho NJM. Social representations of the HIV/AIDS: searching for the senses built for elderly. Rev Pesqui Cuid Fundam [Internet]. 2012 [cited 2017 Jan 27];3(5):121-8. Available from: http://www.seer.unirio.br/index. php/cuidadofundamental/article/view/1960/pdf_532

12. Patel D, Gillespie B, Foxman B. Sexual behavior of older women: results of a random-digit-dialing survey of 2000 women in the United States. STD [internet]. 2003 [cited 2018 Jan 29];30(3):216-20. Available from: https://journals.Iww.com/stdjournal/Abstract/2003/03000/ Sexual_Behavior_of_Older_Women_Results_of_a.8.aspx

13. Costa TLD, Oliveira DCD, Formozo GA. Qualidade de vida e AIDS sob a ótica de pessoas vivendo com o agravo: contribuição preliminar da abordagem estrutural das representações sociais. Cad Saúde Pública [Internet]. 2015 [cited 2016 Dec 21];31(2):365-76. Available from: http://www.scielo.br/pdf/csp/v31n2/0102-311X-csp-31-02-00365.pdf

14. Dantas MDS, Abrão FMDS, Costa SFGD, Oliveira DCD. HIV/AIDS: significados atribuídos por homens trabalhadores da saúde. Esc Anna Nery [Internet]. 2015 [cited 2016 Dec 18];19(2):323-30. Available from: http://www.scielo.br/pdf/ean/v19n2/1414-8145-ean-19-02-0323.pdf

15. Arraes CO, Palos MAP, Barbosa MA, Teles SA, Souza MM, Matos MA. Masculinidade, vulnerabilidade e prevenção relacionadas às doenças sexualmente transmissíveis/HIV/Aids entre adolescentes do sexo masculino: representações sociais em assentamento da reforma agrária. Rev Latino-Am Enfermagem [Internet]. 2013 [cited 2016 Dec 13];21(6):1266-73. Available from: http://www.scielo.br/pdf/rlae/2013nahead/ es_0104-1169-rlae-0104-1169-3059-2363.pdf

16. Moscovici, S. Representações Sociais: investigações em psicologia social. 11ª ed. Petrópolis: Vorazes; 2015.

17. Minayo MCS. Amostragem e saturação em pesquisa qualitativa: consensos e controvérsias. Rev Pesqui Qualit [Internet]. 2017 [cited 2017 Oct 12];5(7):1-12. Available from: http://rpq.revista.sepq.org.br/index.php/rpq/article/view/82

18. Mesquita RF, Matos FRN. A abordagem qualitativa nas ciências administrativas: aspectos históricos, tipologias e perspectivas futuras. Rev Bras Adm Científ [internet]. 2014 [cited 2017 Jan 16];5(1):7-22. Available from: http://sustenere.co/journals/index.php/rbadm/article/view/ SPC2179-684X.2014.001.0001

19. Mesquita RF, Sousa MB, Martins TB, Matos FRN. Obices metodológicos da prática de pesquisa nas ciências administrativas. Rev Pensamento Contemp Adm [Internet]. 2014 [cited 2017 Jan 16];8(1):50-65. Available from: http://www.uff.br/pae/index.php/pca/article/view/387

20. Camargo BV, Justo AM. Tutorial para uso do software de análise textual IRAMUTEQ. Florianopolis [Internet]. 2016 [cited 2016 Dec 12]. Available from: http://www.iramuteq.org/documentation/fichiers/Tutorial\%20IRaMuTeQ\%20em\%20portugues_17.03.2016.pdf

21. Rodrigues PS, Sousa AFLD, Magro MCDS, Andrade DD, Hermann PRDS. Occupational accidents among nursing professionals working in critical units of an emergency service. Esc Anna Nery [Internet]. 2017 [cited 2017 Aug 12];21(2):1-6. Available from: http://www.scielo.br/ pdf/ean/v21n2/en_1414-8145-ean-21-02-e20170040.pdf

22. Sousa AF, Queiroz AA, Oliveira LB, Moura ME, Batista OM, Andrade D. Social representations of biosecurity in nursing: occupational health and preventive care. Rev Bras Enferm [Internet]. 2016 [cited 2017 Jan 12];69(5):864-7. Available from: http://www.scielo.br/pdf/reben/ v69n5/en_0034-7167-reben-69-05-0864.pdf

23. Sousa AF, Queiroz AA, Oliveira LB, Valle AR, Moura ME. Social representations of community-acquired infection by primary care professionals. Acta Paul Enferm [Internet]. 2015 [cited 2017 Jan 12];28(5):454-9. Available from: http://www.scielo.br/pdf/ape/v28n5/ en_1982-0194-ape-28-05-0454.pdf

24. Bezerra VP, Serra MAP, Cabral IPP, Moreira MASP, Almeira SA, Patrício ACFA. Práticas preventivas de idosos e a vulnerabilidade ao HIV. Rev Gaúcha Enferm [Internet]. 2015 [cited 2017 Jan 15];36(4):70-76. Available from: http://www.seer.ufrgs.br/index.php/ RevistaGauchadeEnfermagem/article/view/44787/35668

25. Quadros KN, Campos CR, Soares TE, Resende FM. Perfil epidemiológico de idosos portadores de HIV/AIDS atendidos no serviço de assistência especializada. Rev Enferm Cent O Min [Internet]. 2016 [cited 2017 Jan 19];6(2):2140-6. Available from: http://www.seer.ufsj.edu. br/index.php/recom/article/view/869/1097

26. Cordeiro LI, Lopes TO, Lira LEA, Feitoza SMS, Bessa MEP, Pereira MLD, et al. Validação de cartilha educativa para prevenção de HIV/Aids em idosos. Rev Bras Enferm [Internet]. 2017 [cited 2017 Aug 6];70(4):808-15. Available from: http://www.scielo.br/pdf/reben/v70n4/pt_00347167-reben-70-04-0775.pdf

27. Machado YY, Nogueira VPF, Oliveira DC, Gomes AMT. Representações sociais de profissionais de saúde sobre HIV/AIDS: uma análise estrutural. Rev Enferm UERJ [Internet]. 2016 [cited 2017 Mar 19];24(1):1-6. Available from: http://www.e-publicacoes.uerj.br/index.php/ enfermagemuerj/article/view/14463/17866

28. Oliveira DC. Construção e transformação das representações sociais da Aids e implicações para os cuidados de saúde. Rev Latino-Am Enfermagem [Internet]. 2013 [cited 2017 Jan 18];21(spec):276-86. Available from: http://www.scielo.br/pdf/rlae/v21nspe/pt_34.pdf

29. Crankshaw TL, Voce A, Butler LM, Darbes L. Expanding the relationship context for couple-based HIV prevention: Elucidating women's perspectives on non-traditional sexual partnerships. Soc Sci Med [Internet]. 2016 [cited 2017 Feb 13];166:169-76. Available from: https:// www.ncbi.nlm.nih.gov/pubmed/27566046

30. Nolte K, Kim T, Guthrie B. "Taking Care of Ourselves": The Experiences of Black Women Approaching and Encouraging Male Partners to Test for HIV. J Assoc Nurses AIDS Care [Internet]. 2016 [cited 2017 Feb 22];28(3):327-41. Available from: http://www.sciencedirect.com/science/ article/pii/S1055329016301637 
31. Williams CC, Newman PA, Sakamoto I, Massaquoi NA. HIV prevention risks for Black women in Canada. Soc Sci Med [Internet]. 2009 [cited 2017 Feb 23];68(1):12-20. Available from: http://www.sciencedirect.com/science/article/pii/S0277953608005042

32. Narasimhan M, Payne C, Caldas S, Beard JR, Kennedy CE. Ageing and healthy sexuality among women living with HIV. Reprod Health Matters [Internet]. 2017 [cited 2017 Aug 6];24(48):43-51. Available from: http://www.sciencedirect.com/science/article/pii/ S0968808016300374

33. Villarinho MV, Padilha MI. Sentimentos relatados pelos trabalhadores da saúde frente à epidemia da AIDS (1986-2006). Texto Contexto Enferm [Internet]. 2016 [cited 2017 Feb 13];25(1):1-9. Available from: http://www.scielo.br/pdf/tce/v25n1/en_0104-0707-tce-25-01-0010013. pdf

34. Noar SM, Zimmerman RS, Palmgreen P, Cupp PK, Floyd BR, Mehrotra P. Development and implementation of mass media campaigns to delay sexual initiation among African American and White youth. J Health Commun [Internet]. 2014 [cited 2017 Jan 22];19(2):152-69. Available from: http://www.tandfonline.com/doi/abs/10.1080/10810730.2013.811318

35. Jesmin SS, Chaudhuri S, Abdullah S. Educating women for HIV prevention: does exposure to mass media make them more knowledgeable? Health Care Women Int [Internet]. 2013 [cited 2017 Feb 16];34(3-4):303-31. Available from: https://www.ncbi.nlm.nih.gov/pubmed/23394327

36. Rosenberg MS, Gómez-Olivé FX, Rohr JK, Houle BC, Kabudula CW, Wagner RG, et al. Sexual Behaviorsand HIV Status: a population-based study among older adults in rural South Africa. J Acquir Immune Defic Syndr [Internet]. 2017 [cited 2017 Aug 6];74(1):1-9. Available from: https://www.ncbi.nlm.nih.gov/pmc/articles/PMC5147032/

37. Chollier M, Tomkinson C, Philibert P. STIs/HIV Stigma and health: a short review. Sexol [Internet]. 2016 [cited 2017 Aug 7];25(4):71-5. Available from: http://www.sciencedirect.com/science/article/pii/S1158136016000372

38. Davtyan M, Farmer S, Brown B, Sami M, Frederick T. Women of Color Reflect on HIV-Related Stigma through PhotoVoice. J Assoc Nurses AIDS Care [Internet]. 2016 [cited 2017 Jan 13];27(4):404-18. Available from: https://www.ncbi.nlm.nih.gov/pubmed/27085253

39. Culbert GJ, Earnshaw VA, Wulanyani NMS, Wegman MP, Waluyo A, Altice FL. Correlates and experiences of HIV stigma in prisoners living with HIV in Indonesia: a mixed-method analysis. J Assoc Nurses AIDS Care [Internet]. 2015 [cited 2016 Dec 13];26(6):743-757. Available from:https://www.ncbi.nlm.nih.gov/pmc/articles/PMC4600662/ 